\title{
The dynamic model of partial adjustment of the capital structure. Meta-analysis and a case of Polish enterprises*
}

\author{
Natalia Nehrebecka ${ }^{1}$, Aneta Dzik-Walczak ${ }^{2}$
}

\begin{abstract}
The impact of company characteristics on bank debt financing has always been a field of conflicts among economists (e.g. trade-off theory vs. pecking order theory). The aim of this study is to investigate the adjustment speed of the capital structure to the optimal one. It has been verified how both company characteristics and macroeconomic factors affect adjustments toward a leverage target. This study provides a systematic analysis of the empirical literature on the leverage by conducting a meta-analysis. In particular, the problem of publication selection bias is discussed. Our results indicate that there is an evidence of such publication selection. For Polish case, we have found that the estimation of coefficient for lagged leverage is equal to $58.45 \%$. It means that companies adjust its current level of leverage to the optimal value at a rate of $41.55 \%$ per year, so they need 1.3 years to reduce half of the distance to the optimum leverage. In comparison with results obtained by other researchers, it is relatively high rate of adjustment.
\end{abstract}

Key words: capital structure, leverage, partial adjustment, Polish companies, publication selection bias

JEL classification: $G 32, C 23, C 12, C 13$

\footnotetext{
* Received: 23-10-2017; accepted: 06-06-2018

1 Assistant Professor, Warsaw University - Faculty of Economic Sciences, Dhuga 44/50, 00-241 Warsaw, Poland. National Bank of Poland, Świętokrzyska 11/21, 00-919 Warszawa. Scientific affiliation: econometric methods and models, statistics and econometrics in business, risk modeling and corporate finance. Phone: +48 225549 111. Fax: 2283128 46. E-mail: nnehrebecka@wne.uw.edu.pl.Personal website: http://www.wne.uw.edu.pl/index.php/pl/profile/ view/144/ (corresponding author).

2 Assistant Professor, Warsaw University - Faculty of Economic Sciences, Dhuga 44/50, 00-241 Warsaw, Poland. Scientific affiliation: econometric methods and models, corporate finance. Phone: +48225549 111.Fax: 2283128 46.E-mail: adzik@wne.uw.edu.pl.Personal website: http://www.wne.uw.edu.pl/index.php/pl/profile/view/155/.
} 


\section{Introduction}

Access to finance is one of the key determinants of company growth and expansion. Investment, innovation and survival are not possible without adequate financing. In recent years, the uncertainty and instability caused mainly by the economic crisis has affected businesses. The decreased international demand and increased competitiveness caused that both small and medium sized companies, and large companies faced greater difficulties in sustaining their profit levels and surviving in an unfavourable environment. Modigliani and Miller (1958) formed the basis of modern thinking on capital structure. They claimed that under the assumption of perfect markets where for example taxes and transaction costs do not exist the value of a company would be independent of the capital structure. Nevertheless, subsequent studies have examined the determinants of capital structure and provided new theories with different views on the determinants of capital structure: the pecking order theory, the trade-off theory, the agency theory, the market timing theory.

The aim of this study is to investigate a speed of adjustment of the capital structure to the optimal one. On one hand, we conduct a meta-analysis (based on the meta-regression analysis (MRA) guidelines of Stanley et al. (2013)), we make comparison of results obtained by researchers and verify publication selection bias, on the other, we explore the leverage adjustments for Polish listed companies. This speed of adjustment has been studied widely for developed economies. However, there exists limited research for Polish case. As the institutional structure differs in every country the results of the existing literature shouldn't be generalized to the emerging economies. The dynamic model of partial adjustment of the capital structure reflects the fact that the optimal level of leverage varies between companies and over time. What is interesting is the rate at which leverage converges to its optimal level. The speed of adjustment concept can be successfully applied to evaluate the financing decisions of companies. The added value of this article is an empirical justification that Poland's accession to the EU and access to EU subsidies reduced the demand of small enterprises for financing with external capital in 20042008, and the financial crisis of EU countries (2009-2010) limited financing with external capital.

The paper contributes to the literature on capital structure. The analysis of the company's capital structure, in particular the existence of the target level of leverage and the speed at which the current debt ratio adjusts to the optimal size, is widely recognised by researchers as important and interesting. So far much less attention was devoted to the overall analysis of the existing empirical literature, aimed at drawing a joint conclusion based on statistical premises from the results of many different studies. We start with meta-analysis, the analysis of empirical analyses that attempts to integrate and explain the literature about some specific parameter. To the best of the authors' knowledge, this is the first time a meta-analysis has 
been carried out regarding the estimation of a speed of adjustment of the capital structure. We verify whether previous results on adjustment of the capital structure smoothing are affected by publication bias, which means we test for a tendency to favour significant results and omit insignificant ones (Stanley, 2005). We derive a proxy for the 'true' effect after potential publication bias.

The purpose of meta-analysis is to provide objective and comprehensive summaries of researches conducted by different authors. Meta-analysis is aimed at finding explanation of variation in the regression results published by independent researchers and presenting a statistical conclusion (Sauerbrei and Blettner, 2003).

Due to the fact that the empirical literature is very heterogeneous in terms of used, often incorrect, estimation methods, we test the hypothesis that literature on the capital structure of enterprises is characterized by publication selection bias. Papers detecting weak or insignificant relation are less attractive and rarely published, as they are seen as not adding much to the scientific achievements and do not explain the phenomena of the studied phenomenon. For example, obtained with the Least Squares Method estimator of the speed of capital structure adjustment in the Lemmon et. al. (2008) is characterized by high precision. However, researchers indicate that the OLS estimator is biased in the case of the first order autoregressive process in panel data. Our meta-regression analysis allows to draw a detailed picture on results for different populations or study designs, e.g. methods of estimation. This enables us to provide helpful hints for future research on this topic.

Then we estimate a dynamic econometric model, describing how the long-term and short-term credit contracted by non-financial companies in Poland is determined by proposed set of factors. The financial leverage is the subject of theoretical considerations as well as empirical studies based on financial statements' data, but the cited works do not provide unambiguous conclusions. This analysis extends the current knowledge on factors affecting the level of capital structure of enterprises in Poland. The survey, being built upon the capital structure literature, is original because it has been constructed and conducted on the basis of data for individual companies, providing further evidence of management actively adjusting toward a target. We have analysed financial statements of companies listed on the Warsaw Stock Exchange, New connect or the Central Table of Offers (CeTO), operating in the years 1998-2015. In the estimation we control for three categories of factors: macroeconomic (WIBOR3M and the effective currency rate), microeconomic associated with the internal financial situation and structural. Most other studies adopt a more limited perspective, and as a result provide partial insights. In order to understand the full implications of a capital structure, it is essential to include a macroeconomic perspective. Our examination of capital structure adjustments provides a greater understanding of the mechanisms used in financing decisions of companies. Our estimates of the adjustment rate parameter have a significant and positive impact on the level of leverage, which is confirmed by the assumption 
of dynamic substitution theory, according to which companies seek to achieve an optimal capital structure. Dynamic substitution theory also assumes that the current level of leverage is the weighted average of the optimal ratio of debt to equity and the actual ratio of the previous period.

What's more, it is worth paying attention to the definition of bankruptcy prediction index computed in an innovative way. The indicator allowing to assign the probability of bankruptcy of the company was constructed with the combination of traditional logistic regression with scoring methods. Due to the large number of financial indicators allowing the assessment of the company's condition (explanatory variables) in the initial data analysis, the predictive power of each variable was determined (Gini coefficient, Information Value (IV)), and then clustering was applied to limit the dimensions of the analysis. The analysis was carried out on categorized variables transformed with WoE (Weight of Evidence) transformation. Scoring methods were used to divide enterprises due to the risk of bankruptcy.

We verify the hypothesis about the predominance of postulates of trade-off theory over the postulates of pecking order theory in processes determining the volatility of financial leverage among Polish listed companies, regardless of the industry and size of the company. It was expected that Polish listed companies have an optimal level of leverage, and in the case of shocks, they quickly adjust the current debt ratio to the optimal level (as in Flannery and Rangan (2006) research).

An interesting economic situation and the actions of the Monetary Policy Council in the analyzed period of time lead to the inclusion in the study of the impact of monetary policy on the financing structure of Polish listed companies. The monetary policy transmission mechanism describes how economic agents react to decisions of Monetary Policy Council. Cook and Tang (2010) and Baum et. al. (2017) confirm that the macroeconomic situation determines the use of financial leverage by enterprises. Although the results obtained by Lemmon et al. (2008) show a lack of dependence between macroeconomic variables and the level of leverage. We test whether monetary policy through the interest rate and exchange rate channels has a significant impact on the amount of leverage.

The remainder of this paper is organized as follows. Section 2 discusses the prior literature's examination of target leverage, the costs and benefits of leverage, and how companies may adjust leverage. The hypotheses of interest are provided in Section 3 and 4. Section 3 describes meta-analysis. Section 4 discusses the data, methodology, and the variables employed in the study. A discussion regarding the results and implications is provided in Section 6. 


\section{Literature review}

An overview of the literature related to the theory of capital structure is presented below. We concentrate on the estimators of speed adjustment coefficient. The authors use for estimation a two-stage and integrated dynamic model of a partial adaptation.

The dynamic model of partial adjustment of the capital structure reflects the fact that the optimal level of leverage varies between companies and over time. The model allows to estimate the parameter of the speed of adjustment. It is assumed that the optimal level of debt ratio $Y_{i t}^{*}$ is a function of $k$ explanatory variables, as in the equation given below.

$$
Y_{i t}=\sum_{k=1} \varphi_{k} X_{k i t}+\omega_{i t}
$$

where $X$ is a vector of $k$ explanatory variables, $\omega_{i t}$ is serially correlated random error with a zero mean and a possible heteroscedasticity, $\varphi_{k}$ is unknown parameter identical for all companies. This equation allows to investigate the existence of an optimal capital structure for each company, which is determined by macroeconomic and microeconomic factors. Because of transaction costs, companies are not able to match the current level of leverage for the optimal level immediately. According to Leary and Roberts (2005) companies correct variations in capital structure on average once a year. Relatively rare adjustment processes offset the cost of staying outside the optimal level of leverage and transaction costs. The two-stage dynamic model of partial adjustment shows that companies adapt their current level of leverage $Y_{i t}$ to the optimal level at a rate of $\theta$ :

$$
Y_{i t}-Y_{i t-1}=\theta\left(Y_{i t}^{*}-Y_{i t-1}\right)
$$

where the fitted value of the dependent variable is an approximation of the optimal leverage $Y_{i t}^{*}$. According to the model assumptions $\theta$ takes a value in the range of $(0,1)$ because of the transaction costs. $\theta$ equal to 1 means that the current change in the level of leverage is equal to the expected, and the adjustment process contains no transaction costs. $\theta$ equal to zero means no change in the level of leverage. It is possible in a situation of extremely high adjustment costs that exceed the cost of deviation from the optimal level of leverage. In this case, companies establish the current level of the debt ratio at the level from previous period $Y_{i t-1}$.

Substituting equation (1) into (2) an integrated dynamic model of partial adaptation is obtained.

$$
Y_{i t}=(1-\theta) Y_{i t-1}+\Sigma_{k=1} \theta \varphi_{k} X_{k i t}+\theta \omega_{i t}
$$

In the above equation, the coefficient for lagged dependent variable is $(1-\theta)$, where $\theta$ measures how quickly the company adjust the current level of leverage to the optimal size. 
The researchers, that used a two-stage model are e.g. Fama and French (2002), Brav (2009) and Baum et al. (2017).

Fama and French (2002) analyse how the long-term leverage ratio and dividend payout vary between companies depending on profitability and investment opportunities (variables proposed by two competing models - model of substitution and the hierarchy of sources of funding). The sample used in the study covers the period from 1965 to 1999 for more than 3000 companies. The optimum level of leverage is an unobservable variable. Therefore, authors first perform regression for current leverage on the set of lagged variables that are determinants of optimal capital structure. Fitted values obtained from this regression are then as an approximation of the optimal level of leverage. Leverage converges to the optimal level at a rate of $7-10 \%$ per year for companies paying dividend and $15-18 \%$ for the others. The same approach was proposed by Brav (2009), who aimed to find differences in the choice of funding between public and private British companies. Based on FAME (Forecasting Analysis and Modelling Environment) data for years 1993-2003 he found that private companies to a greater extent use debt, have higher leverage and tend to avoid external capital markets. Private companies are characterize by slower rate of adjustment to the optimal leverage level $(10.2 \%$ vs. $22.5 \%$ for public companies).

In order to estimate the two-stage model of partial adjustment Kayhan and Titman (2007) and Faulkender et al. (2012) use the least squares method with bootstrap. Based on Compustat database covering the period from 1960 to 2003 they analysed the impact of cash flow, capital expenditures and stock prices on the debt ratio. The results obtained indicate that the companies slowly adjust the current debt ratio to the target level - at 10\% per annum. Faulkender et al. (2012) explore how financial constraints affect the adjustment to an optimal debt ratio. Based on Compustat database that cover the period from 1965 to 2006 they point that companies that have better access to external capital are characterized by higher rate of adjustment to the optimal level of leverage.

Dang, Kim and Shin (2012) analyze adjustments toward target leverage based on panel of UK companies. The speed of adjustment is estimated at $53-59 \%$ what means that companies can reduce more than a half of their deviation from target leverage within a year. The Authors conclude that that companies adjusting relatively quickly have a large and positive financing deficit. The speed of adjustment is different for different subsamples. Low-growth and highgrowth companies adjust toward their target leverage at the rates of 54\% and $70 \%$, respectively. The speed of adjustment seems to be faster for companies with large investment (77\%) than for those with small investment (59\%). The speeds of adjustment for companies with low and high profitability are $64 \%$ and $74 \%$. Probably highly levered companies with low profitability revert to target leverage to avoid financial distress. The speed of adjustment seems to be faster 
for small companies $(77 \%)$ than for large companies $(62 \%)$. It is in line with the argumentation that due to facing lower cash flow volatility and financial distress costs as well as fewer debt covenants, large companies have less incentive and external pressure to adjust capital structures. Indeed, companies with low and high earnings volatility adjust at different rates (67\% vs $56 \%)$.

Baum et al. (2017) study the impact of macroeconomic and firm-specific risk on the parameter of the speed of adjustment of the capital structure. They use a twostage model of partial adjustment. The study was conducted at the unbalanced panel data from the Worldscope Global database covering the period from 1981 to 2009 years. Companies with too high level of leverage quickly adapt to the optimal level if macroeconomic risk is low. Conversely, companies with too low leverage adjust their capital structure more rapidly in a period of low firm-specific risk and high macroeconomic risk.

Caglayan and Rashid (2014) investigate the effects of idiosyncratic and macroeconomic risk on companies' leverage in UK. They include one-period lagged leverage in the function form of the model to control persistence in leverage. The authors hypothesize that the sensitivity of leverage to explanatory variables differs across the public and nonpublic companies. They find that lagged leverage attains a positive impact in case of both types of companies. However, the size of the coefficient for nonpublic companies is significantly larger than that of public companies. According to the authors it implies that nonpublic companies' leverage has a greater persistence, nonpublic companies depend more on short-term debt while public companies have a wider choice to finance business.

Flannery and Rangan (2006) and Cook and Tang (2010) used both the two-step and integrated models of partial adjustment. Flannery and Rangan (2006) have shown that the estimator for rate of adjustment is significantly lower than theory predicts in a two-stage version of the model. Cook and Tang (2010) analyse the impact of macroeconomic conditions on the speed of adjustment of the current level of leverage to the optimal value. They confirmed that the two-stage model estimation results in obtaining much lower estimator for speed of adjustment than integrated model.

Ozkan (2001), Xu (2007), Antoniou et al. (2008), Huang and Ritter (2009) and Florysiak and Elsas (2015) estimate the rate of adjustment using the dynamic model of the integrated partial adjustment. Obtained estimates for the speed of adjustments are higher than in the case of two-stage method. Slow adjustment indicates that the passed financial activity plays a significant role in shaping the current capital structure. This means that companies do not have the optimal level of leverage, or the desire to achieve it is not important. On the contrary, high rate of adjustment suggests that history does not matter, and that benefits and costs associated with financial policy determines the optimal capital structure. 


\section{Methodology}

\subsection{Meta-analysis}

Stanley and Jarrell (1989) considered why do researchers come to such different findings when they are investigating the same phenomenon. Is it because of statistical methods, model misspecifications, different data sets? The authors offered a quantitative methodology for reviewing the empirical economic literature. Proposed meta-regression analysis is the regression analysis of regression analyses. Meta-regression analysis not only recognizes the specification problem but also attempts to estimate its effects by modelling variations in selected econometric specifications.

Estimates of parameter of adjustment show a significant and positive impact on the level of leverage, which confirms the assumptions of the dynamic theory of substitution. Dynamic substitution theory also assumes that the current level of leverage is a weighted average of the optimal ratio of debt to equity and real relationship with the previous period. However, it is likely that obtained results could be due to publication selection effect. It occurs when researchers and reviewers prefer obtaining statistically significant results as works which find weak dependence or lack of significance are less attractive and less published.

The funnel graph is a classic method used for the identification of the publication selection bias. It is a distribution diagram for the precision (measured usually as the inverse of the standard error) from the estimated coefficient. In the case of the absence of the publication selection bias, the diagram should resemble an upside down funnel - wide at the base, tapering as the values on the vertical axis increase. The funnel diagram should also be symmetrical, regardless of the value of the true effect, at which the estimations should converge.

In order to identify if there is publication bias in our meta-samples we follow Stanley et al. (2008) and we estimate equation (4). It is so called Funnel Asymmetry Test.

$$
t_{i}=\beta_{0}+\beta_{1}\left(\frac{1}{S E_{i}}\right)+v_{i}
$$

where:

$t_{i}$ - test statistics $t, S E_{i}-$ standard error, $\beta_{0}, \beta_{1}$ - unknown parameters, $v_{i}-$ random error.

It is worth considering possible within-study dependence, as multiple estimates from the same studies are with high probability statistically dependent. We have chosen the mixed-effects multilevel (MEM) model that takes into account both 
within and between study variations. The overall error term includes the studylevel random-effects and measurement error disturbance term in this approach. Furthermore, we test the robustness of our results by applying clustered data analysis (CDA). All WLS estimations use either inverse variance or sample size weights.

\subsection{A case of Polish listed enterprises}

A dynamic econometric model has been estimated, describing how the long-term and short-term credit contracted by non-financial companies in Poland is affected by three categories of factors: macroeconomic (WIBOR $3 M$ and the real effective currency rate), microeconomic - associated with the internal financial situation and structural. Parameters were estimated using the robust system GMM (Generalised Methods of Moments) estimator (see: Arellano \& Bover, 1995; Blundell \& Bond, 1998). In addition, a resistant variance-covariance matrix was used. The estimation method was selected correspondingly to the definition of response variables and the problem of endogeneity identified and confirmed in tests. The correctness of the instrument mix was verified by means of the Sargan test, conducted to check if the condition of orthogonality between the instruments and the random component was satisfied. This condition was verified using a test for autocorrelation in differences of remainders from the model. The model design assumption requires that there should be no correlation of the remainder component of degree 2 and higher degrees. In descriptive statistics and histograms of continuous variables, a significant percent of atypical observations can be found in all samplings. With regard to the variable probability distribution, $5 \%$ of the most extreme values were replaced with the quantile value of 0.95 or 0.05 , depending on the feature distribution. This allowed the investigation of dependences between the response variable variability and the explanatory variables variability without losing relevant information. The test was preceded by an estimation of the correlation between the explanatory variables.

\section{Empirical data and analysis}

\subsection{Meta-analysis}

We identified our relevant primary studies in an extensive search using Google scholar, EconLit, and Scopus. We searched using the broad keywords: "Capital structure" "SOA" "Leverage + SOA," and "Speed of Adjustment". Due to a large number of papers providing the estimates for the speed of adjustment meta-analysis seems to be an appropriate tool summarizing current results. Examinations of titles, abstracts, and keywords were followed by the inspection of the introduction and conclusion. These studies were published by about 70 researchers. We then checked whether those studies are based on empirical estimations. We excluded studies 
which are an earlier version of a subsequently published paper as well as studies that fail to report standard errors with the regression results as the availability of the latter is crucial for the estimation of publication bias. In addition, we eliminated analysis for binary outcome, e.g. using vs not using external capital. Finally, we have analysed 187 regressions from 33 articles. Table A1 summaries the results obtained by the researchers. Table 1 provides the descriptive statistics for $S O A$ Effects. On the basis of descriptive statistics, it should be noted that there are no outliers (the median value is basically similar to the average). In addition, the density estimator was estimated and coincides with the normal distribution.

Table 1: Speed of Adjustment of the Capital Structure (SOA Effects) reported in 34 Studies Published in 1984-2017

\begin{tabular}{|c|l|c|c|c|c|c|c|}
\hline Variable & $\begin{array}{c}\text { The direction } \\
\text { of impact }\end{array}$ & \# regressions & Mean & Median & SE & Minimum & Maximum \\
\hline \multirow{2}{*}{ SOA } & $\begin{array}{l}\text { Positive } \\
\text { and Statistically } \\
\text { Significant }\end{array}$ & 177 & \multirow{2}{*}{$36,6 \%$} & $34,4 \%$ & $20,5 \%$ & $3,3 \%$ & $84,3 \%$ \\
\cline { 2 - 8 } & $\begin{array}{l}\text { Negative and } \\
\text { Statistically } \\
\text { Significant }\end{array}$ & 0 & 10 & & & & \\
\cline { 2 - 8 } & Not significant & 10 & & & & \\
\hline
\end{tabular}

Source: Authors' calculations

Some complications have arisen when trying to create a funnel graph is the fact that or two-stage or integrated dynamic model of partial adjustment of the capital structure is used. The first model gives direct estimation of speed adjusting (Speed Of Adjustment $S O A$ ) with its standard error, while the second estimates $1-S O A$. As a result in the second case the authors indicate the standard error of $1-S O A$, not $S O A$. Therefore, in the present work it was decided to present two funnel graphs. The first graph was made on the basis of 62 observations, while the other 125 observations.

The first graph (Figure 1) looks like a half of a funnel graph. It should be noted that the adjustment coefficient takes values between 0 and 1 . The average of the three upper points is equal to $15 \%$. In the case that the results obtained by the researchers are not biased, they should distract symmetrically around this point. However, the average of all estimates is $35 \%$ - much more than the top of the chart. This indicates the existence of a publication selection effect. It is worth noting that many econometric decisions, such as the omission of variables, the choice of estimation methods or function forms of the model can also change the shape of the graph. Figure 1 also indicates the existence of a publication selection effect. 
Figure 1: Funnel Plot of Speed of Adjustment of the Capital Structure (SOA Effects) for All-Studies

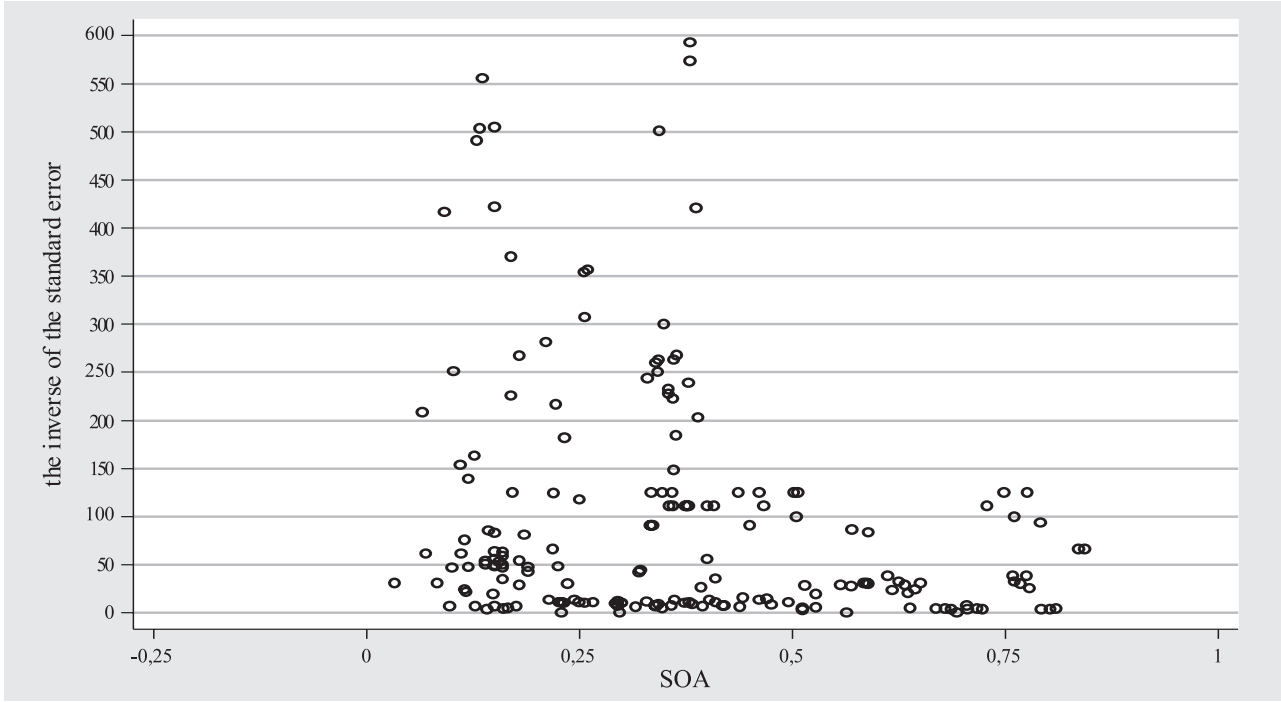

Source: Authors' calculations

Table 2 reports the results for the univariate FAT-PET Meta-Regression Analysis. Testing whether the constant is equal to zero $\left(\mathrm{H}_{0}: \beta_{0}=0\right)$ is equivalent to the testing of distribution asymmetry and can be used as the measurement of the occurrence of the effect of the publication selection bias, $\beta_{0}$ estimate indicates the direction of the bias (Egger et al., 1997; Stanley, 2008; Stanley, Doucouliagos, 2012).

Table 2: Univariate MRA for FAT-PET of SOA Effects

\begin{tabular}{|l|c|c|}
\hline \multirow{2}{*}{ Variables } & \multicolumn{2}{|c|}{ Coefficient } \\
\cline { 2 - 3 } & (CDA: clustered data analysis) & $\begin{array}{c}\text { (MEM: mixed-effects multilevel } \\
\text { model) }\end{array}$ \\
\hline \multirow{2}{*}{$1 /$ se (PET) } & $\begin{array}{c}0.247^{* * *} \\
(0.012)\end{array}$ & $\begin{array}{c}0.233^{* * *} \\
(0,024)\end{array}$ \\
\hline Constant (FAT) & $\begin{array}{c}5.486 * * * \\
(1.976)\end{array}$ \\
\hline Number of observation & \multicolumn{2}{|c|}{187} \\
\hline
\end{tabular}

Note: $* * * * *, *$ donate the significance level of $1 \%, 5 \%, 10 \%$ respectively. Robust standard errors are reported in the parenthesis. Test for between study heterogeneity (Q-test) is $82,072.47^{* * *}$ on 186 degrees of freedom with p-value less than 0.001 and I2 statistics (variation in SOA estimates attributable to heterogeneity) is $99.0 \%$. Model 1 (MEM: mixedeffects multilevel model) estimated through the restricted maximum likelihood, whereas Model 2 (CDA: clustered data analysis) from study level clustered standard errors.

Source: Authors' calculations 
Obtained result $\left(\mathrm{H}_{0}: \beta_{0}=0 ; C D A\right.$ (clustered data analysis): estimator $=5.486$; $\mathrm{p}$-value $=0.012<0.05 ; M E M($ mixed-effect multilevel model): estimator $=6.022$; p-value $=0.024<0.05$ ) indicates rejection of the null hypothesis of the absence of publication selection effect. In the specifications of model, the PET consistently suggests the exist of a genuine effect.

Figure 2: Time trend of Speed of Adjustment of the Capital Structure (SOA Effects)

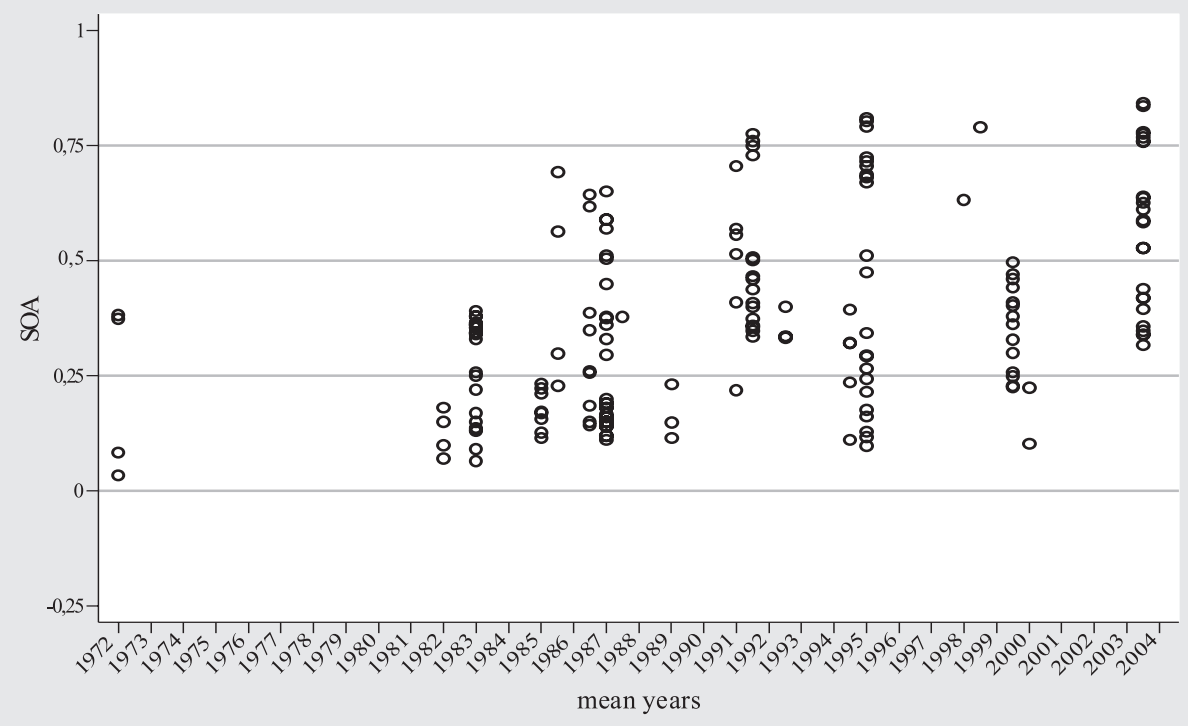

Source: Authors' calculations

In the next step, we verify the dependence of the parameter of adjustment on the year of the study (Figure 2). The analysis of the graph shows that the majority of studies was conducted between 1982 and 1995. The value of estimator increase in time. Many authors have estimated this parameter based on 1995's data. After 1995 obtained coefficients indicate lower rate of adjustment.

\subsection{A case of Polish listed enterprises}

In our empirical analysis, we employ an unbalanced panel of listed companies. Database was created on the basis of the financial statements of companies listed on the Warsaw Stock Exchange, Newconnect or the Central Table of Offers (CeTO), operating in the years 1998-2015. We focused on non-financial enterprises, which, according to the Central Statistical Office results in exclusion from the study companies operating (according to the Polish Classification of Activities, 2007) in section $A$ (Agriculture, forestry, hunting and fishing), $K$ (Financial and insurance 
activities) and $O$ (public administration and defence, compulsory social security). In addition, section $T$ (Activities of households, households producing goods and providing services for their own needs) and Section $U$ (extraterritorial organizations and bodies) were removed. Furthermore, some variables include outliers in only the upper values, so we truncate the sample at the 99 percentile to exclude these outliers. Table A2 describes the variables used in the debt of listed enterprises model in Poland.

Table 3: Descriptive statistics of variables used in the debt of listed enterprises model in Poland

\begin{tabular}{|l|r|r|r|r|r|r|c|}
\hline \multicolumn{1}{|c|}{ Variable } & Mean & Std. dev & Q1 & Median & Q3 & Min & Max \\
\hline Debt & 0,3928 & 0,2137 & 0,2240 & 0,3814 & 0,5493 & 0,0000 & 0,9821 \\
\hline Revenues (in millions) & 537 & 2769 & 22 & 79 & 255 & 0,0000 & 79000 \\
\hline Profitability & 0,0691 & 0,0846 & 0,0015 & 0,0465 & 0,0965 & 0,0000 & 0,7770 \\
\hline Collateral & 0,2661 & 0,2218 & 0,0729 & 0,2224 & 0,4102 & 0,0000 & 0,9673 \\
\hline Non-interest tax shield & 0,0363 & 0,0334 & 0,0136 & 0,0294 & 0,0489 & 0,0000 & 0,4537 \\
\hline Interest tax shield & 0,0066 & 0,0105 & 0,0000 & 0,0000 & 0,0101 & 0,0000 & 0,0354 \\
\hline Intangible assets & 0,0312 & 0,0796 & 0,0008 & 0,0048 & 0,0198 & 0,0000 & 0,8654 \\
\hline Growth opportunities & 0,1630 & 0,3772 & $-0,0537$ & 0,0942 & 0,2989 & $-0,4331$ & 1,1907 \\
\hline Current ratio measure & 2,2986 & 1,9178 & 1,1179 & 1,5883 & 2,6870 & 0,5611 & 8,3258 \\
\hline Effective tax rate & 0,0669 & 0,1103 & 0,0000 & 0,0000 & 0,1480 & 0,0000 & 0,3420 \\
\hline Inverted index bankruptcy & 1,0447 & 2,2484 & 0,3887 & 1,0000 & 1,8662 & $-4,6108$ & 6,1899 \\
\hline Median sector debt & 0,3737 & 0,0949 & 0,3089 & 0,3552 & 0,4397 & 0,2477 & 0,6204 \\
\hline
\end{tabular}

Source: Authors' calculations

Table 3 provides some summary statistics. As shown, the average share of total liabilities in the balance sheet total amounts is about $40 \%$, which means that the Polish listed companies to a large extent finance with the external capital. In the sample leverage ranges from 0 to $98 \%$. Analysing the chart of variation of leverage over time we see that the highest average amount of leverage was achieved in 2002, which was the result of significant increases in the stock market. A significant decrease in leverage in 2007 was a reaction to the restrictive monetary policy a rise in interest EURIBOR $3 M$ and $L I B O R 3 M$, as well as the growing trend of market interest rates on bank loans, interest WIBOR $3 M$. The increase in market interest rates on bank loans and interest WIBOR $3 M$ resulted in a decrease in debt lasting until the beginning of 2008. In 2011, an increase in leverage was observed in response to the decline in market interest rates on bank loans and interest rates in 2010. Restrictive monetary policy in 2000, 2004 and 2007 resulted in a decrease in leverage. On the other hand, the policy of low interest rates in 2003 and 2006 and in the years 2009-2010 (WIBOR3M and market interest rates on loans) caused 
an increase in leverage. This points to the fact that monetary policy determines the structure of financial companies.

\section{Results and discussion}

\subsection{Meta-analysis}

We investigated whether the SOA effect is genuine or affected by publication bias using funnel plots, FAT-PET meta-analytical approaches. Our research clearly uncovers that publication bias is a problem for this field and we establish the extent and source of the bias. We indicated that PET-FAT results suggest that both publication bias and genuine effect exist, then there is a nonlinear relationship between reported SOA effect and its standard error.

One of the reasons may be model misspecification, not proper method of estimation. Another reason for the observed effect may be pressure to obtain statistically significant and high rate of speed adjustment which would indicate the confirmation of the existence of an optimal level of leverage and the theory of substitution. Therefore, most of the published studies has high statistically significant estimates. In addition, studies are carried out on different samples, including various lengths of time, which could also affect the shape of the graph.

The Meta-Regression Analysis methodology focuses on controlling publication bias, reducing omitted variable bias and endogeneity issues across the studies under review. Without having corrections for publication bias, an empirical literature which appears to present a given empirical effect could be misleading (Stanley, 2008) and therefore could impede policy formulation.

\subsection{A case of Polish listed enterprises}

A dynamic econometric model has been estimated, describing how the long-term and short-term credit contracted by non-financial companies in Poland is affected by three categories of factors: macroeconomic (3-month WIBOR interest rate and the real effective currency rate), microeconomic - associated with the internal financial situation and structural (Table A3). Parameters were estimated using the robust system GMM (Generalised Methods of Moments) (see: Arellano \& Bover, 1995; Blundell \& Bond, 1998).

According to the static and dynamic theory of trade-off the companies maintain the optimal level of leverage, and quickly adapt to the aimed value in the case of any deviations. The theory of the hierarchy of sources of funding and market timing exclude the existence of an optimal debt ratio. Researchers verify the validity of these theories by estimation of coefficient of the speed of adjustment. A high value 
of coefficient confirms the validity of the theory of trade-off. Based on the literature, it was observed that the coefficient reaching a value above $20 \%$ is considered to be high. However, the authors suggest that the slow rate of adjustment does not indicate a rejection of the hypothesis according to which the companies have an optimal capital structure. This slow rate may result from the existence of high adjustment costs that exceed the costs of staying outside the optimum. In our study the estimate of coefficient for lagged dependent variable ((Long-term debt + Shortterm debt) / Total assets) is $58.45 \%$. It means that companies adjust its current level of leverage to the optimal value at a rate of $41.55 \%$ per year. Therefore companies need 1.3 years to reduce half of the distance to the optimum leverage. In comparison with results obtained by other researchers it is relatively high rate. The high values, $34 \%$ and $46 \%$ were received, among others, by Flannery and Rangan (2006) and Cook and Tang (2010) respectively. Fama and French (2002) and Huang and Ritter (2009) interpret the obtained slow rate of adjustment to support the theory of the hierarchy of sources of funding.

Enterprise size seems to be one of the most theorized determinants of financial leverage, explained by most capital structure theories. However, still much remains unclear and uncertain, while the pecking-order hypothesis upholds the negative relation between size and leverage, the trade-off theory seems to have proposed otherwise. According to our results, in Poland the size of the company shows a positive correlation with the level of leverage. Large enterprises finance investments through external sources, in particular the long-term bank loan and sale of securities. Companies that generate higher revenues, having more bargaining power and better access to credit have lower credit margins and increased external capital in the capital structure. Smaller companies finance mainly with profits generated or contributions owners. We confirm the assumption of the pecking-order theory that more profitable companies have a smaller share of external capital in total assets. Companies adhere to a hierarchy of financing sources and prefer to use internal rather than external finance. Companies capable to generate high profits have a greater tendency to use equity than external capital. We find that debt decreases with increasing effective tax rate. High taxes result from the large revenues that reduce the need for debt. It can be expected that growing companies have a greater need of capital, and therefore rely on external financing. The increase in sales may not able to meet the financial needs due to the problem of gridlock. Our results confirm this expectations, we indicate a positive correlation between the level of leverage and growth opportunities. Tangible fixed assets may be treated as a collateral. The higher share of fixed assets in total assets reduces the lender's risk and increases the access to external capital, which is consistent with the theory of trade-off. Agency costs and information asymmetry can cause that lenders require guarantees in the form of collateral on fixed assets, and therefore expected positive impact of this variable on the size of the debt ratio. The variable asset structure works with lags, as the basis for verification of the credit are the financial statements for the 
previous year. Liquidity is defined as the company's ability to timely repayment of current liabilities. Companies with high liquidity have a greater ability to pay the debt and therefore should use the external capital as a main source of funding. We got a positive relation between the level of debt and liquidity, which testifies to the support of the theory of substitution. Non-interest tax shield is an important factor affecting the capital structure. It arises as a result of the existence of other than interest on borrowed capital, items that reduce the tax base, such as depreciation. In our study, non-interest tax shield reduces debt, which indicates that companies use rather depreciation than the interest paid on the debt. The results are consistent with the theory of substitution. In turn, the interest tax shield has a positive impact on the level of leverage. It is assumed that companies with high expenditure on research and development prefer equity financing. However, our results indicate a positive relationship between intangible assets and the debt ratio. According to the theory of signalling, a well-developing companies increase the involvement of external capital to signal the good prospects for the future.

In the case of other explanatory variables used in the model, theories regarding the choice of the capital structure does not give a clear indication as to the direction of the expected impact on the level of debt. The negative impact of the inverted index bankruptcy on leverage points to the fact that companies having a higher probability of bankruptcy are less likely to benefit from the financing of external capital. This may involve the fact that the threatened with bankruptcy companies will not be able to repay its liabilities. The median leverage in the sector is an important determinant of the debt ratio. Companies operating in the same industry are affected by a similar environment: market fluctuations, the impact of state institutions or changes in the market of suppliers and customers, which indicates the existence of a positive relationship between the variables.

The survey was repeated for industrial and service companies separately. High rate of adjustment of the current level of debt to the optimal level for both industrial (35.83\%) and service companies (41\%) proves the existence of an optimal capital structure and rapid effort to achieve it, regardless of the industry. The results are just slightly different in terms of the factors that influence the choice of debt in these two sectors of the economy. In both subgroups the same variables occurred to be significant determinants of debt. However, for industrial company growth opportunities and the share of intangible assets in total assets have a negative impact on the dependent variable. The negative relationship between the debt and growth opportunities, according to the theory of substitution, reflects that costs of the financial risk (including bankruptcy) increase with the expected growth of the company, forcing managers to reduce debt in the capital structure. For service companies the relation is consistent with the theory of the hierarchy of sources of funding. Summing up, the influence of most variables used in the model indicates to the theory of substitution in case of Polish listed companies, irrespective of the sector of the business. 
Due to the fact that the size of the company may affect its access to capital markets, the risk of bankruptcy and economies of scale in contracting capital, a model was estimated for small and large companies separately. An important conclusion derived from the analysis is that large companies slowly adjust the current level of debt to the optimal size. The adjustment rate for large companies is only $23.54 \%$, while in the case of small companies it is $44.55 \%$. This is because large companies are characterized by lower volatility of cash flow, and therefore meet lower costs associated with a deviation from an optimal debt. Although the adjustment process in large companies is slower than in small companies, based on the literature for both cases it is referred as fast.

It turns out that for large companies, as in the case of industrial companies, growth opportunities and the share of intangible assets in total assets are negatively correlated with the level of debt. This is because the highly developing smaller businesses have a greater financial needs, so they lend more. The increase in sales is not able to meet the financial needs of small businesses because of the gridlock. For large companies an increase in sales growth increase the possibility of selffinancing, which reduces the need for external financing. In large companies, payment backlogs are of minor importance, and sales growth results in an increase in revenues from debt repayment. Another difference between small and large companies is the negative impact of collateral on the level of leverage in the case of large enterprises. Higher fixed assets increase the availability of external capital as they reduce the risk of the lender. Therefore, the positive impact of collateral on debt is expected. However, for large enterprises increase in fixed assets reduces the demand for external capital financing. For smaller companies assets held in year $t-1$ increase debt, as they constitute collateral. This is because the basis for verification of the creditworthiness is the financial statements for the previous year. Moreover, in the case of large companies, variable non-interest tax shield is irrelevant. This is due to the fact that large businesses borrow more in order to maximize tax benefits. Smaller companies receive tax savings mainly due to depreciation, rather than the interest paid on the debt. Despite minor differences in the estimates of parameters, the impact of most variables points to the application of the theory of substitution in Polish listed companies, regardless of company size.

In our study the estimate of coefficient for lagged leverage $58.45 \%$. It means that companies adjust its current level of leverage to the optimal value at a rate of $41.55 \%$ per year (which means that companies need 1.3 years to reduce half of the distance to the optimum leverage). In comparison with results obtained by other researchers it is relatively high rate. The high values, $34 \%$ and $46 \%$ were received, among others, by Flannery and Rangan (2006) and Cook and Tang (2010) respectively. Fama and French (2002) and Huang and Ritter (2009) interpret the obtained slow rate of adjustment to support the theory of the hierarchy of sources of funding. 
The survey was repeated for industrial and service companies separately. High rate of adjustment of the current level of debt to the optimal level for both industrial (35.83\%) and service companies (41\%) proves the existence of an optimal capital structure and rapid effort to achieve it, regardless of the industry.

The adjustment rate for large companies is only $23.54 \%$, while in the case of small companies it is $44.55 \%$. This is because large companies are characterized by lower volatility of cash flow, and therefore meet lower costs associated with a deviation from an optimal debt. Although the adjustment process in large companies is slower than in small companies, based on the literature for both cases it is referred as fast.

\section{Conclusions}

In this study we have analysed the adjustment speed of the capital structure to the optimal one. This study pursues two objectives: on one hand, we conduct a metaanalysis, we make comparison of results differentiating between publications and verify publication selection bias, on the other, we explore the determinants of leverage for Polish listed companies.

In summary, the results obtained by a meta-analysis indicate the effect of selection of publications. One of the reasons may be model misspecification, not proper method of estimation. Another reason for the observed effect may be pressure to obtain statistically significant and high rate of speed adjustment which would indicate the confirmation of the existence of an optimal level of leverage and the theory of substitution. Therefore, most of the published studies have high statistically significant estimates. In addition, studies are carried out on different samples, including various lengths of time, which could also affect the shape of the graph.

Due to the fact that the size of the company may affect its access to capital markets, the risk of bankruptcy and economies of scale in contracting capital, a model was estimated for small and large companies separately. An important conclusion derived from the analysis is that large companies slowly adjust the current level of debt to the optimal size.

\section{References}

Abdeljawad, I. et al. (2013) "Dynamic Capital Structure Trade-off Theory: Evidence from Malaysia", International Review of Business Research Papers, Vol. 9, No. 6, pp. 102-110.

Antoniou, A., Guney, Y., Paudyal, K. (2008) "The determinants of capital structure: Capital market oriented versus bank-oriented institutions", Journal of Financial 
and Quantitative Analysis, Vol. 43, No. 1, pp. 59-92, doi: 10.1017/S0022109 000002751.

Arellano, M., Bond, S. (1991) "Some Tests of Specification for Panel Data", Review of Economic Studies, Vol. 58, No. 2, pp. 277-297, doi: 10.2307/2297968.

Arioglu, E., Tuan, K. (2014) "Speed of adjustment: Evidence from Borsa Istanbul", Borsa Istanbul Review, Vol. 14, No. 2, pp. 126-131, doi: 10.1016/j.bir.2014.02.002.

Baum, C.F., Caglayan, M., Rashid, A. (2017) "Capital structure adjustments: do macroeconomic and business risks matter?", Empirical Economics, Springer, Vol. 53, No. 4, pp. 1463-1502, doi: 10.1007/s00181-016-1178-1.

Baum, C.F., Stephan A., Talavera, O. (2009) "The effects of uncertainty on the leverage of nonfinancial companies", Economic Inquiry, Vol. 47, No. 2, pp. 216-225, doi: 10.1111/j.1465-7295.2007.00116.x.

Benito, A. (2003) "The capital structure decisions of companies: is there a pecking order?", Banco de España; Working, Vol. 0310, Available at: <https://www.bde. es/f/webbde/SES/Secciones/Publicaciones/PublicacionesSeriadas/ DocumentosTrabajo/03/Fic/dt0310e.pdf >, [Accessed: April 16, 2018].

Blundell, R.W., Bond, S.R. (1998) "Initial Conditions and Moment Restrictions in Dynamic Panel Data Models", Journal of Econometrics, Vol. 87, No. 1, pp. 115-143, doi: 10.1016/s0304-4076(98)00009-8.

Brav, O. (2009) "Access to capital, capital structure, and the funding of the firm", Journal of Finance, Vol. 64, No. 1, pp. 263-308, doi: 10.1111/j.1540-6261. 2008.01434.x.

Byoun, S. (2008) "How and When Do Companies Adjust Their Capital Structures toward Targets?", Journal of Finance, Vol. 63, No. 6, pp. 3069-3096, doi: 10.1111/j.1540-6261.2008.01421.x.

Caglayan, M., Rashid, A. (2014) "The response of company leverage to uncertainty: Evidence from UK public versus non-public companies", Economic Inquiry, Vol. 52, No. 1, pp. 341-363, doi: 10.1111/ecin.12042.

Chang, X., Dasgupta, S. (2009) "Target behavior and financing: How conclusive is the evidence?", Journal of Finance, Vol. 64, No. 4, pp. 1767-1796, doi: 10.1111/j.1540-6261.2009.01479.x.

Cook, D.O., Tang, T. (2010) "Macroeconomic conditions and capital structure adjustment speed", Journal of Corporate Finance, Vol. 16, No. 1, pp. 73-87, doi: 10.1016/j.jcorpfin.2009.02.003.

Dang, V., Kim M., Shin Y. (2012) "Asymmetric capital structure adjustments: New evidence from dynamic panel threshold models", Journal of Empirical Finance, Vol. 19, No. 4, pp. 465-482, doi: 10.1016/j.jempfin.2012.04.004.

(2014) "Asymmetric adjustment toward optimal capital structure: Evidence from a crisis", International Review of Financial Analysis, Vol. 33, No. 1, pp. 226-242, doi: 10.1016/j.irfa.2014.02.013. 
Dang, V.A., Garrett, I. (2015), “On corporate capital structure adjustments", Finance Research Letters, Vol. 14, No. 1, pp. 56-63, doi: 10.1016/j.frl.2015.05.016.

Drobetz, W., Schilling, D.C., Schroder, H. (2014) "Heterogeneity in the Speed of Capital Structure Adjustment across Countries and over the Business Cycle", European Financial Management, Vol. 21, No. 5, pp. 936-973, doi: 10.1111/ eufm.12048.

Egger, M. et al. (1997) "Bias in meta-analysis detected by a simple, graphical test", British Medical Journal, Vol. 316, No. 1, pp. 629-634, doi: 10.1136/bmj.315. 7109.629.

Elsas, R., Florysiak D. (2015) "Dynamic capital structure adjustment and the impact of fractional dependent variables", Journal of Financial and Quantitative Analysis, Vol. 50, No. 5, pp. 1105-1133, doi: 10.1017/S0022109 015000496.

(2011) "Heterogeneity in the speed of adjustment toward target leverage", International Review of Finance, Vol. 11, No. 2, pp. 181-211, doi: 10.1111/j. 1468-2443.2011.01130.x.

Fama, E.F., French, K.R. (2002) "Testing trade-off and pecking order predictions about dividends and debt", Review of Financial Studies, Vol. 15, No. 1, pp. 1-33, doi: 10.1093/rfs/15.1.1.

------- (2005) "Financing decisions: Who issues stock?”, Journal of Financial Economics, Vol. 76, No. 1, pp. 549-582, doi: 10.1016/j.jfineco.2004.10.003.

(2012) “Capital structure choices", Critical Finance Review, Vol. 1, No. 1, pp. 59-101, doi: 10.1561/103.00000002.

Fama, E.F., MacBeth, J.D. (1973) "Risk, Return, and Equilibrium: Empirical Tests", Journal of Political Economy, Vol. 81, No. 1, pp. 607-636, doi: 10.1086/ 260061.

Faulkender, M. et al. (2012) "Cash flows and leverage adjustments", Journal of Financial Economics, Vol. 103, No. 3, pp. 632-646, doi: 10.1016/j.jfineco. 2011.10.013.

Fier, S.G., Kathleen, A., Carson, J.M. (2013) "Internal capital markets and the partial adjustment of leverage", Journal of Banking \& Finance, Vol. 37, No. 3, pp. 1029-1039, doi: 10.1016/j.jbankfin.2012.11.003.

Flannery, M.J., Rangan, K.P. (2006) "Partial adjustment toward target capital structures", Journal of Financial Economics, Vol. 79, No. 3, pp. 469-506, doi: 10.1016/j.jfineco.2005.03.004.

Flannery, M.J., Hankins, K.W. (2013) "Estimating dynamic panel models in corporate finance", Journal of Corporate Finance, Vol. 19, No. 1, pp. 1-19, doi: 10.1016/j.jcorpfin.2012.09.004.

Hovakimian, A., Li, G. (2011) "In search of conclusive evidence: How to test for adjustment to target capital structure", Journal of Corporate Finance, Vol. 17, No. 1, pp. 33-44, doi: 10.1016/j.jcorpfin.2010.07.004. 
Huang, R., Ritter, J.R. (2009) "Testing theories of capital structure and estimating the speed of adjustment", Journal of Financial and Quantitative Analysis, Vol. 44, No. 2, pp. 237-271, doi: 10.1017/S0022109009090152.

Iliev, P., Welch, I. (2010) "Reconciling Estimates of the Speed of Adjustment of Leverage Ratios", SSRN Electronic Journal, Vol. 1, No. 1, pp.1-49, doi: 10.2139/ssrn.1542691.

Jalilvand, A., Harris, R. (1984) "Corporate behavior in adjusting to capital structure and dividend targets: An econometric study", Journal of Finance, Vol. 39, No. 1, pp. 127-145, doi: 10.1111/j.1540-6261.1984.tb03864.x.

Kayhan, A., Titman, S. (2007) "Companies' histories and their capital structures", Journal of Financial Economics, Vol. 83, No. 1, pp. 1-32, doi: 10.1016/j. jifineco.2005.10.007.

Leary, M., Roberts, M. (2005) "Do companies rebalance their capital structures?", Journal of Finance, Vol. 60, No. 1, pp. 2575-2619, doi: 10.1111/j.1540-6261. 2005.00811.x.

Lemmon, M.L., Roberts, M.R., Zender, J.F. (2008) "Back to the beginning: Persistence and the cross-section of corporate capital structure", Journal of Finance, Vol. 63, No. 4, pp. 1575-1608, doi: 10.1111/j.1540-6261.2008.01369.x.

Miller, M., Modigliani, F. (1958) "The Cost of Capital, Corporation Finance and The Theory of Investment", The American Economic Review, Vol. 48, No. 1, pp. 261-297.

Mukherjee, T., Wang, W. (2015) "Corporate governance and capital structure dynamics: an empirical study", The Journal of Financial Research, Vol. 38, No. 2, pp. 169-192, doi: 10.1111/jfir.12057.

Nehrebecka, N., Dzik-Walczak A. (2016), "Construction measures of bankruptcy: case study of Polish enterprises", Global Business and Economics Review, Vol. 18, No. 3/4, pp. 420-444, doi: 10.1504/GBER.2016.076234.

Ozkan, A. (2001) "Determinants of capital structure and adjustment to long run target: Evidence from UK company panel data", Journal of Business Finance \& Accounting, Vol. 28, No. 1-2, pp. 175-198, doi: 10.1111/1468-5957.00370.

Oztekin, O., Flannery, M.J. (2012) "Institutional determinants of capital structure adjustment speeds", Journal of Financial Economics, Vol. 103, No. 1, pp. 88-112, doi: 10.1016/j.jfineco.2011.08.014.

Sauerbrei, W., Blettner, M. (2003) "Issues of traditional reviews and meta-analyses of observational studies in medical research", in "Meta-analysis: New Developments and Applications in Medical and Social Sciences", ed. R. Schulze, H. Holling, D. Böhning, Hogrefe \& Huber, München.

Stanley, T.D., Jarrell, S.B. (1989) "Meta-regression analysis: A quantitative method of literature surveys", Journal of Economic Surveys, Vol. 3, No. 2, pp. 161-170, doi: 10.1111/j.1467-6419.1989.tb00064.x. 
Stanley, T.D., Doucouliagos, H., Giles, M., Heckemeyer, J.H., Johnston, R.J., Laroche, P., Nelson, J.P., Paldam, M., Poot, J., Pugh, G., Rosenberger, R.S. and Rost, K. (2013) "Meta-Analysis of Economics Research Reporting Guidelines", Journal of Economic Surveys, Vol. 27, No. 2, pp. 390-394, doi: 10.1111/joes.12008.

Stanley, T.D. (2005) "Beyond Publication Selection", Journal of Economic Surveys, Vol. 19, No. 3, pp. 309-345, doi: 10.1111/j.0950-0804.2005.00250.x.

Welch, I. (2004), "Capital structure and stock returns", Journal of Political Economy, Vol. 112, No. 1, pp. 106-131, doi: 10.1086/379933.

$\mathrm{Xu}, \mathrm{Z}$. (2007) "Do companies adjust toward a target leverage level?", Working paper, Bank of Canada, pp. 1-39, doi: 10.2139/ssrn.888743. 


\title{
Dinamički model djelomične prilagodbe strukture kapitala. Meta-analiza i slučaj poljskih poduzeća
}

\author{
Natalia Nehrebecka ${ }^{1}$,Aneta Dzik-Walczak ${ }^{2}$
}

\begin{abstract}
Sažetak
Utjecaj karakteristika poduzeća na bankovno financiranje dugova uvijek je bilo polje sukoba među ekonomistima (teorija izbora financiranja vs. teorija redoslijeda financiranja). Cilj ovog rada je istražiti brzinu prilagodbe strukture kapitala na optimalnu strukturu. Potvrđeno je da i karakteristike poduzeća $i$ makroekonomski čimbenici utječu na prilagodbe prema ciljanoj strukturi izvora financiranja. Ova studija sustavno analizira empirijsku literaturu o učinku financijske poluge uz primjenu meta analize. Posebno se raspravlja o problemu pristrane selekcije publikacija. Rezultati ukazuju na postojanje dokaza o takvom odabiru publikacija. U slučaju Poljske, pronašli smo da je procjena koeficijenta lagirane financijske poluge jednaka $58,45 \%$. To znači da poduzeća prilagođavaju trenutnu razinu poluge do optimalne vrijednosti po stopi od 41,55\% godišnje, pa im je potrebno 1,3 godine da se smanji polovica udaljenosti do optimalne poluge. U usporedbi s rezultatima drugih istraživača, radi se o relativno visokoj stopi prilagodbe.
\end{abstract}

Ključne riječi: struktura kapitala, utjecaj, djelomična prilagodba, poljske tvrtke, pristranost odabira publikacija

JEL klasifikacija: G32, C23, C12, C13

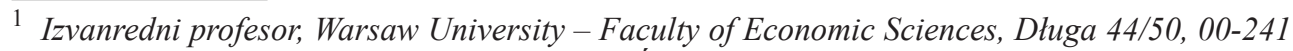
Varšava, Poljska. National Bank of Poland, Świętokrzyska 11/21, 00-919 Varšava. Znanstveni interes: ekonometrijske metode i modeli, statistika i ekonometrija u poslovanju, modeliranje rizika i korporativne financije. Tel.: +48 225549 111. Fax: 2283128 46. E-mail: nnehrebecka@wne.uw.edu.pl. Osobna web stranica: http://www.wne.uw.edu.pl/index.php/pl/ profile/view/144/ (corresponding author).

2 Izvanredni profesor, Warsaw University - Faculty of Economic Sciences, Dluga 44/50, 00-241 Varšava, Poljska. Znanstveni interes: ekonometrijske metode i modeli, statistika i ekonometrija u poslovanju, modeliranje rizika i korporativne financije. Tel.: +48 225549 111. Fax: 22831 28 46. E-mail: adzik@wne.uw.edu.pl. Osobna web stranica: http://www.wne.uw.edu.pl/ index.php/pl/profile/view/155/. 
Natalia Nehrebecka, Aneta Dzik-Walczak • The dynamic model of partial adjustment...

\section{Appendices}

Table A1: List of articles included in the last phase of the meta-regression database for SOA Effects

\begin{tabular}{|c|c|c|c|c|}
\hline Article & Sample & Country & SOA $(\%)$ & Half-Life \\
\hline Abdeljawad et al. (2013) & $1992-2009$ & Malaysia & $70,6-97,7$ & $0,2-0,6$ \\
\hline Antoniou et al. (2008) & $1987-2000$ & UK & $32,0,32,2$ & $1,8,1,8$ \\
\hline Arioglu, Tuan (2014) & $1998-2010$ & Turkish & $50,8-70,3$ & $1,0-4,2$ \\
\hline Baum, Caglayanc, Rashid (2017) & $1981-2009$ & $\begin{array}{c}\text { United } \\
\text { Kingdom }\end{array}$ & $22,1-32,2$ & $1,8-2,9$ \\
\hline Baum, Stephan and Talavera (2009) & $1993-2003$ & USA & 63,3 & 0,7 \\
\hline Benito (2003) & $1998-2000$ & Spain & $33,3-64,4$ & $0,7-1,7$ \\
\hline Brav (2009) & $1997-2003$ & UK & $10,2,22,5$ & $6,4,2,7$ \\
\hline Byoun (2008) & $1971-2003$ & USA & $33,0,20,0$ & $1,7,3,1$ \\
\hline Caglayan and Rashid (2014) & 1999-2008 & UK & $31,9-84,3$ & $0,4-1,8$ \\
\hline Chang and Dasgupta (2009) & 1971-2004 & USA & 37,8 & 1,4 \\
\hline Cook and Tang (2010) & $1977-2006$ & USA & $46,1,43,7$ & $1,1,1,2$ \\
\hline Dang and Garrett (2015) & $1971-2003$ & USA & $29,2-33,3$ & $1,7-2$ \\
\hline Dang et al. (2012) & 1996-2003 & UK & $22,6-49,6$ & $1,0-2,7$ \\
\hline Dang, Kim, Shin (2014) & $2002-2012$ & USA & $28,1-36,2$ & $1,5-2,1$ \\
\hline $\begin{array}{l}\text { Drobetz, Schilling, } \\
\text { Schroder (2013) }\end{array}$ & $1992-2011$ & G-7 & $8,9-41,3$ & 3 \\
\hline Elsas and Florysiak (2011) & 1965-2009 & USA & $50,5,45,0$ & $1,0,1,1$ \\
\hline Elsas and Florysiak (2015) & $1965-2009$ & USA & 26,0 & 2,3 \\
\hline Elsas et al. (2014) & $1989-2006$ & USA & $27-43$ & $1,2-2,2$ \\
\hline Fama and French (2002) & 1965-1999 & USA & $10,0,18,0$ & $6,6,3,5$ \\
\hline Faulkender et al. (2012) & $1965-2006$ & USA & $22,9,69,3$ & $2,6,0,6$ \\
\hline Fier, Kathleen, Carson (2013) & 1996-2009 & - & 19 & 3,3 \\
\hline Flannery and Hankins (2013) & $1968-2004$ & USA & 22,0 & 2,8 \\
\hline Flannery and Rangan (2006) & $1965-2001$ & USA & 34,0 & 1,7 \\
\hline Hovakimian and Li (2011) & $1970-2007$ & USA & $13,2-35,7$ & $1,6-4,9$ \\
\hline Huang and Ritter (2009) & $1963-2001$ & USA & 17,0 & 3,7 \\
\hline Iliev, Welch (2010) & $1963-2007$ & USA & 1,04 & 6,3 \\
\hline Jalilvand and Harris (1984) & 1966-1978 & USA & $56,1,10,9$ & $0,8,6,0$ \\
\hline Kayhan and Titman (2007) & $1960-2003$ & USA & 10,0 & 6,6 \\
\hline Lemmon et al. (2008) & $1963-2003$ & USA & 25,0 & 2,4 \\
\hline Mukherjee and Wang (2015) & $1965-2008$ & USA & $7-36$ & $4,6-5,5$ \\
\hline Ozkan (2001) & 1984-1996 & UK & 56,9 & 0,8 \\
\hline Oztekin and Flannery (2012) & 1991-2006 & 37 countries & 79,1 & 0,44 \\
\hline Welch (2004) & $1962-2000$ & USA & 0 & 0,1 \\
\hline $\mathrm{Xu}(2007)$ & 1970-2004 & USA & 18,0 & 3,5 \\
\hline
\end{tabular}

Source: Authors' calculations 
Natalia Nehrebecka, Aneta Dzik-Walczak • The dynamic model of partial adjustment...

Table A2: Description of variables used in the debt of listed enterprises model in Poland

\begin{tabular}{|l|l|}
\hline \multicolumn{1}{|c|}{ Variable } & \multicolumn{1}{c|}{ Definition } \\
\hline Debt 1 & (Long-term debt + Short-term debt) / Total assets \\
\hline Debt 2 & Short-term debt / Total assets \\
\hline Debt 3 & $\begin{array}{l}\text { (Long-term debt + Short-term debt) / (Total debt + Equity } \\
\text {-Revaluation reserve) }\end{array}$ \\
\hline \multicolumn{2}{|l|}{ Companies' characteristics } \\
\hline Company size & Logarithm of revenues \\
\hline Profitability & EBIT/ total assets \\
\hline Collateral & Tangible assets/total assets \\
\hline Non-interest tax shield & Depreciation/total assets \\
\hline Interest tax shield & Interest/total assets \\
\hline Intangible assets & Intangible assets /total assets \\
\hline Growth opportunities & $\begin{array}{l}\text { Revenue from sales (t) - Revenue from sales (t-1)) / Revenue } \\
\text { from sales (t-1) }\end{array}$ \\
\hline Current ratio measure & Current assets/Short-term liabilities \\
\hline Quick ratio measure & Current assets and inventories/Short-term liabilities \\
\hline Effective tax rate & The current part of income tax/profit before tax \\
\hline Inverted index bankruptcy & Nehrebecka, Dzik (2016) \\
\hline Grants & Binary variable, takes 1 if company got grants \\
\hline IAS & $\begin{array}{l}\text { Binary variable, takes 1 if company have set of basic accounting } \\
\text { records which are prepared and audited in line with IAS }\end{array}$ \\
\hline & \multicolumn{2}{|l|}{ Macroeconomic variables } \\
\hline GDP & The growth of Gross Domestic Product \\
\hline WIBOR3M & 3-month WIBOR interest rate \\
\hline REER & Effective rate of exchange \\
\hline &
\end{tabular}

Source: Authors' calculations 
Natalia Nehrebecka, Aneta Dzik-Walczak • The dynamic model of partial adjustment... Zb. rad. Ekon. fak. Rij. • $2018 \cdot$ vol. $36 \cdot$ no. $1 \cdot 55-81$

\begin{tabular}{|c|c|c|c|c|c|c|c|c|c|c|c|c|c|c|c|c|}
\hline & * & ** & * & & * & $\mid \begin{array}{l}* \\
* \\
* \\
*\end{array}$ & * & $\mid \begin{array}{l}* \\
* \\
* \\
*\end{array}$ & $\begin{array}{l}* \\
* \\
* \\
* \\
*\end{array}$ & $\begin{array}{l}* \\
* \\
* \\
*\end{array}$ & $\begin{array}{l}* \\
* \\
* \\
*\end{array}$ & $\begin{array}{l}* \\
* \\
* \\
*\end{array}$ & * & $\begin{array}{l}* \\
* \\
* \\
*\end{array}$ & * & * \\
\hline 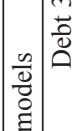 & $\begin{array}{ll}n & 0 \\
n & 0 \\
\infty & 0 \\
n & 0 \\
0 & 0 \\
0 & 0\end{array}$ & & 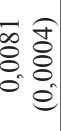 & $\mid \begin{array}{ll}m & 2 \\
\infty & 2 \\
0 & 8 \\
0 & 0 \\
1 & 0\end{array}$ & 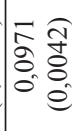 & 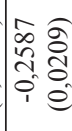 & {$\left[\begin{array}{ll}\pi & \approx \\
0 & 0 \\
0 & 0 \\
+ & 0 \\
-0 & 0 \\
& 0\end{array}\right.$} & $\mid \begin{array}{ll}1 & 0 \\
8 & 0 \\
0 & 0 \\
0 & 0 \\
& 0\end{array}$ & 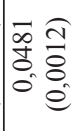 & 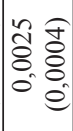 & $\mid \begin{array}{ll}\infty & 0 \\
0 & 0 \\
0 & 0 \\
0 & 0 \\
1 & 0\end{array}$ & $\left|\begin{array}{ll}\varkappa & \widehat{8} \\
8 & 8 \\
0 & 8 \\
1 & 0\end{array}\right|$ & $\mid \begin{array}{ll}8 & 0 \\
0 & 0 \\
0 & 8 \\
0 & 0 \\
0\end{array}$ & 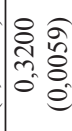 & $\mid \begin{array}{ll}n & \sigma \\
\delta & \bar{g} \\
0 & 0 \\
1 & 0\end{array}$ & $\mid \begin{array}{ll}\infty & 0 \\
0 & 0 \\
0 & 8 \\
0 & 0 \\
0 & 0\end{array}$ \\
\hline $\mid \begin{array}{l}\vec{y} \\
\overrightarrow{0} \\
0\end{array}$ & $\begin{array}{l}* \\
* \\
*\end{array}$ & * & * & * $*$ & * & 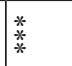 & $\underset{*}{*} *$ & $* *$ & $* *$ & $*$ & $* *$ & * & $* *$ & * & $\underset{*}{*} *$ & $\begin{array}{l}* \\
* \\
*\end{array}$ \\
\hline 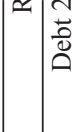 & 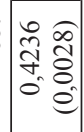 & & 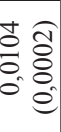 & $\mid \begin{array}{ll}1 & 0 \\
\infty & 0 \\
0 & 0 \\
0 & 0 \\
1 & 0 \\
1 & 0\end{array}$ & 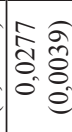 & 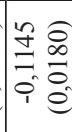 & 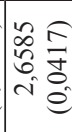 & 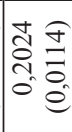 & 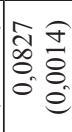 & $\mid \begin{array}{ll}\infty & \widehat{1} \\
0 & 0 \\
0 & 8 \\
0 & 0 \\
0 & 0 \\
1 & 0\end{array}$ & 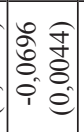 & $\left|\begin{array}{ll}\vec{\delta} & \widehat{\delta} \\
8 & 8 \\
0 & 8 \\
1 & 0\end{array}\right|$ & 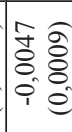 & 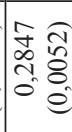 & $\mid \begin{array}{ll}2 & \\
\delta & \bar{\sigma} \\
8 & 8 \\
0 & 0 \\
0\end{array}$ & 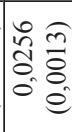 \\
\hline$\stackrel{8}{\Omega}$ & * & $\underset{*}{*} *$ & * & $*$ & 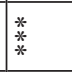 & & $\begin{array}{l}* \\
* \\
* \\
*\end{array}$ & $\begin{array}{l}* \\
* \\
*\end{array}$ & $*$ & * & $* *$ & * & & $\begin{array}{l}* \\
* \\
*\end{array}$ & * & * $*$ \\
\hline 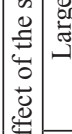 & 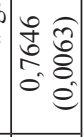 & & 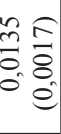 & 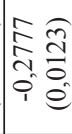 & 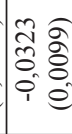 & 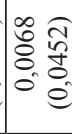 & $\mid \begin{array}{ll}1 & 0 \\
0 & 0 \\
6 & 0 \\
- & 0 \\
-0 & 0\end{array}$ & 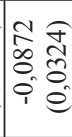 & $\begin{array}{ll}0 & 0 \\
0 & 0 \\
0 & 8 \\
1 & 0\end{array}$ & $\mid$\begin{tabular}{ll}
0 & - \\
\hdashline & 0 \\
0 & 8 \\
0 & 0
\end{tabular} & $\mid \begin{array}{cc}0 & \widehat{a} \\
0 & 0 \\
0 & \delta \\
0 & 0 \\
1 & 0\end{array}$ & $\left|\begin{array}{ll}\infty & 0 \\
8 & 0 \\
0 & 8 \\
1 & 0 \\
1 & 0\end{array}\right|$ & 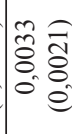 & $\mid \begin{array}{ll}0 & 0 \\
0 & 0 \\
0 & 0 \\
0 & 0\end{array}$ & 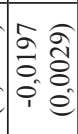 & 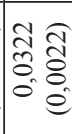 \\
\hline 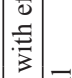 & $\begin{array}{l}* \\
* \\
*\end{array}$ & * & * & $*$ & $*$ & * & $\begin{array}{l}* \\
* \\
*\end{array}$ & $\begin{array}{l}* \\
* \\
*\end{array}$ & * & $* *$ & $* *$ & $\underset{*}{*} * \underset{*}{*}$ & 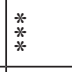 & $\begin{array}{l}* \\
* \\
* \\
*\end{array}$ & * & $* *$ \\
\hline & 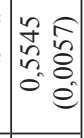 & & 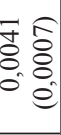 & \begin{tabular}{ll}
1 & 0 \\
\multirow{2}{*}{0} & 0 \\
0 & 0 \\
0 & 0
\end{tabular} & 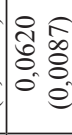 & $\mid \begin{array}{ll}2 & \approx \\
0 & \approx \\
0 & 0 \\
0 & 0 \\
1 & 0\end{array}$ & $\mid \begin{array}{ll}n & f \\
2 & f \\
0 & 0 \\
-0 & 0\end{array}$ & 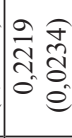 & $\mid \begin{array}{ll}\hat{a} & \widehat{\widehat{o}} \\
0 & \delta \\
0 & 0 \\
0 & 0\end{array}$ & $\mid \begin{array}{ll}\bar{r} & 0 \\
\delta & 8 \\
0 & 8 \\
0 & 0\end{array}$ & $\mid \begin{array}{ll}\vec{B} & 0 \\
0 & 0 \\
0 & 0 \\
0 & 0 \\
1 & 0\end{array}$ & 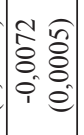 & $\mid \begin{array}{ll}8 & 0 \\
0 & 0 \\
0 & 8 \\
1 & 0 \\
1 & 0\end{array}$ & 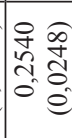 & 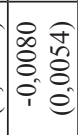 & $\mid \begin{array}{ll}i & 0 \\
n & 0 \\
0 & 0 \\
0 & 0 \\
1 & 0\end{array}$ \\
\hline 莞 & $\begin{array}{l}* \\
* \\
*\end{array}$ & * & * & * & * & $\begin{array}{l}* \\
* \\
*\end{array}$ & $*$ & $* *$ & * & * & $\begin{array}{l}* \\
* \\
*\end{array}$ & * & $\begin{array}{l}* \\
* \\
* \\
*\end{array}$ & $\underset{*}{*}$ & * & * $*$ \\
\hline 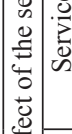 & $\mid \begin{array}{ll}8 & 0 \\
0 & 0 \\
0 & 0 \\
0 & 0 \\
0 & 0\end{array}$ & & 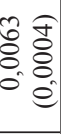 & 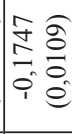 & 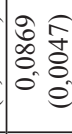 & 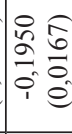 & $\begin{array}{ll}n & 0 \\
0 & 0 \\
0 & n \\
-0 & 0 \\
-0\end{array}$ & 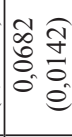 & 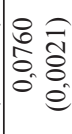 & $\mid \begin{array}{ll}n & 0 \\
2 & 0 \\
8 & 8 \\
0 & 0 \\
0 & 0\end{array}$ & $\mid \begin{array}{cc}m & \\
\tilde{y} & \tilde{n} \\
0 & 0 \\
0 & 0 \\
1 & 0\end{array}$ & $\left|\begin{array}{ll}n & \widehat{0} \\
0 & 8 \\
0 & 0 \\
1 & e\end{array}\right|$ & 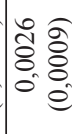 & 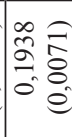 & $\mid \begin{array}{ll}5 & \approx \\
0 & \tilde{o} \\
0 & 0 \\
0 & 0\end{array}$ & 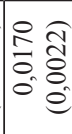 \\
\hline & 跣 & * & * & $\begin{array}{l}* \\
* \\
* \\
*\end{array}$ & $*$ & * & $\begin{array}{l}* \\
* \\
*\end{array}$ & $*$ & $*$ & * & $\begin{array}{l}* \\
* \\
*\end{array}$ & * & \begin{tabular}{|l|}
$*$ \\
$*$ \\
$*$ \\
$*$
\end{tabular} & * & * & * \\
\hline 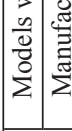 & 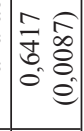 & & 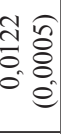 & 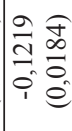 & $\mid \begin{array}{ll}0 & 0 \\
0 & 0 \\
0 & 0 \\
0 & 0\end{array}$ & 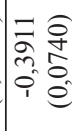 & 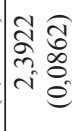 & $\mid \begin{array}{ll}\pi & \widehat{\sigma} \\
\infty & 0 \\
0 & + \\
0 & 0 \\
1 & 0 \\
0\end{array}$ & 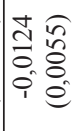 & $\mid \begin{array}{ll}i & 0 \\
\delta & 8 \\
0 & 0 \\
0 & 0 \\
0 & 0\end{array}$ & $\mid \begin{array}{ll}0 & \widehat{a} \\
0 & 0 \\
0 & 0 \\
0 & 0 \\
1 & 0\end{array}$ & $\mid \begin{array}{ll}1 & \hat{0} \\
8 & 8 \\
0 & 0 \\
1 & 0\end{array}$ & $\mid \begin{array}{ll}n & 0 \\
\cdots & 0 \\
0 & 8 \\
0 & 0 \\
0 & 0\end{array}$ & 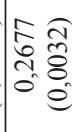 & 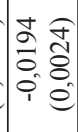 & $\mid \begin{array}{ll}n & 0 \\
\widehat{0} & \delta \\
0 & 8 \\
0 & 0\end{array}$ \\
\hline $\bar{\nabla}=$ & $\begin{array}{l}* \\
* \\
*\end{array}$ & * & * & $*$ & $*$ & $*$ & $* *$ & $*$ & * & $* *$ & $\begin{array}{l}* \\
* \\
*\end{array}$ & * & * & $\begin{array}{l}* \\
* \\
* \\
*\end{array}$ & $* *$ & $\begin{array}{l}* \\
* \\
*\end{array}$ \\
\hline 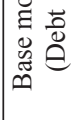 & 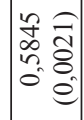 & & $\begin{array}{ll}\pi & 0 \\
8 & 8 \\
0 & 8 \\
0 & 0\end{array}$ & $\mid \begin{array}{ll}9 & 0 \\
0 & 0 \\
0 & 8 \\
0 & 0 \\
1 & 0\end{array}$ & 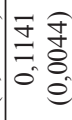 & $\begin{array}{ll}\pi & 0 \\
2 & 0 \\
2 & 0 \\
0 & 0 \\
0 & 0\end{array}$ & 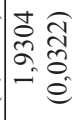 & 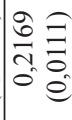 & $\begin{array}{ll}\infty & 0 \\
\infty & n \\
0 & 8 \\
0 & 8 \\
0 & 0\end{array}$ & 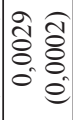 & 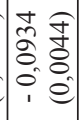 & $\mid \begin{array}{cc}\tilde{\delta} & \widehat{0} \\
8 & 8 \\
0 & 8 \\
1 & 0\end{array}$ & $\mid \begin{array}{ll}2 & 0 \\
0 & 0 \\
0 & 0 \\
0 & 0 \\
0\end{array}$ & 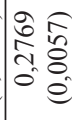 & $\mid \begin{array}{ll}2 & 0 \\
\delta & 0 \\
\delta & 8 \\
0 & 0 \\
1 & 0\end{array}$ & 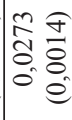 \\
\hline 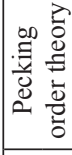 & & & & & & & & & + & & & & & & & \\
\hline 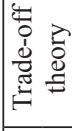 & & 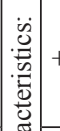 & + & $\frac{1}{1}$ & + & & & & & + & & & & & & \\
\hline 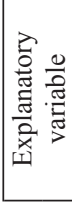 & $\begin{array}{l}I \\
\Xi \\
. \Xi \\
00 \\
0 \\
0\end{array}$ & 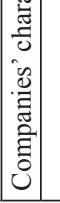 & 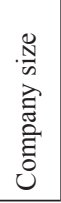 & 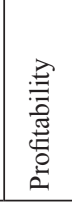 & 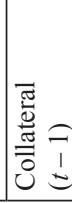 & 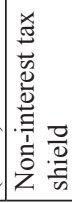 & 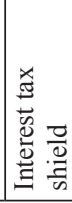 & 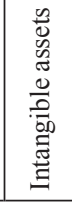 & 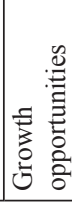 & 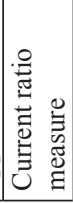 & 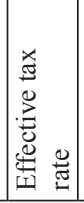 & 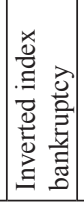 & 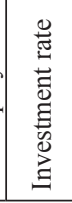 & 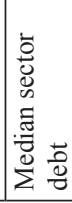 & 䓪 & $\mathbb{Z}$ \\
\hline
\end{tabular}


Natalia Nehrebecka, Aneta Dzik-Walczak • The dynamic model of partial adjustment...

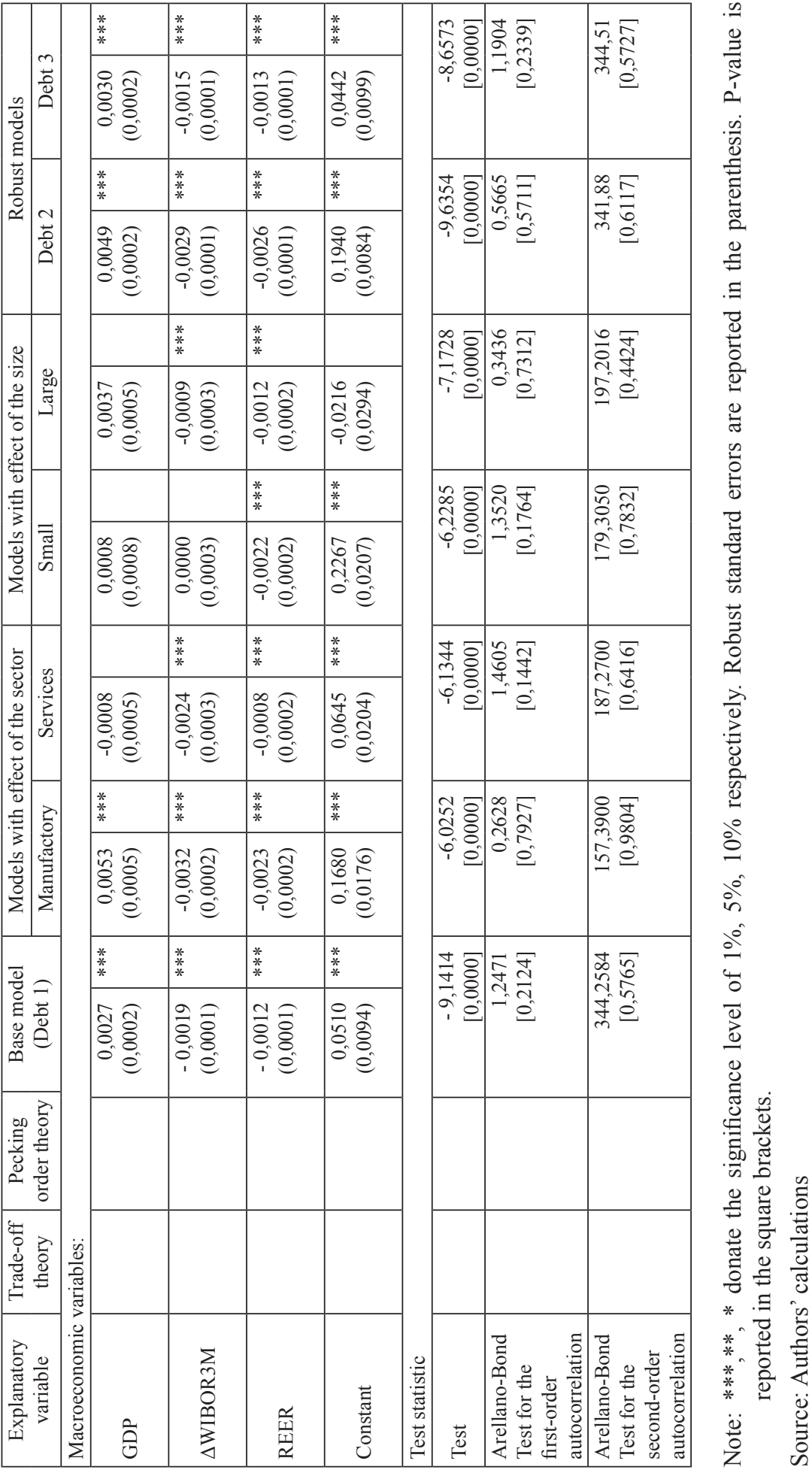

